(C) 2002 Plant Management Network.

Accepted for publication 14 October 2002. Published 18 October 2002.

\title{
Management of Early Leaf Spot of Peanut with Pyraclostrobin as Affected by Rate and Spray Interval
}

\author{
A. K. Culbreath, T. B. Brenneman, and R. C. Kemerait, J r., \\ Department of Plant Pathology, The University of Georgia, Coastal \\ Plain Experiment Station, Tifton, 31793-0748
}

Corresponding author: A. K. Culbreath. leafspot@tifton.uga.edu

Culbreath, A. K., Brenneman, T. B., and Kemerait, R. C., J r. 2002. Management of early leaf spot of peanut with pyraclostrobin as affected by rate and spray interval. Online. Plant Health Progress doi: 10.1094/PHP-2002-1018-01-RS.

\begin{abstract}
Field tests were conducted in Tifton, Georgia, in 1998 to 2000 and in Plains, Georgia, in 1999 and 2000 to determine the efficacy of pyraclostrobin on early leaf spot (Cercospora arachidicola) of peanut (Arachis hypogaea). Application regimes included three rates $(112,168$, and $224 \mathrm{~g}$ a.i./ha) of pyraclostrobin applied on 14-, 21-, and 28-day schedules. These were compared to currentlyused fungicides chlorothalonil, tebuconazole, and azoxystrobin. In all tests, application of pyraclostrobin at rates of $168 \mathrm{~g} / \mathrm{ha}$ or higher gave better leaf spot control than chlorothalonil applied at $1.26 \mathrm{~kg} / \mathrm{ha}$ or tebuconazole applied at 227 $\mathrm{g} / \mathrm{ha}$ on the same schedule. At both Plains and Tifton, plots treated four times with pyraclostrobin at 168 or $224 \mathrm{~g} /$ ha on a 28-day schedule had final leaf spot intensity ratings that were similar to those of standard rates of chlorothalonil or tebuconazole applied seven times on a 14-day schedule. At Tifton, all three rates of pyraclostrobin applied five times on a 21-day schedule had final leaf spot ratings lower than those of plots treated with seven applications of chlorothalonil or tebuconazole on a 14-day schedule. There was little improvement in leaf spot control with rates of pyraclostrobin higher than $168 \mathrm{~g} / \mathrm{ha}$ in any test or application schedule. Fungicide effects on yield were not consistent, but in all tests, yields from plots treated with any of the three rates of pyraclostrobin were similar to or higher than yields from plots treated with $227 \mathrm{~g} / \mathrm{ha}$ of tebuconazole on the same schedule. The ability to use pyraclostrobin at 21-day intervals and maintain control of early leaf spot similar to that of application of currently available fungicides at 14-day intervals represents potential savings in time, fuel, labor, and equipment costs.

\section{I ntroduction}

If not controlled, early leaf spot, caused by Cercospora arachidicola S. Hori, (Fig. 1) and late leaf spot, caused by Cercosporidium personatum (Berk. \& M. A. Curtis) Deighton, diseases of peanut (Arachis hypogaea L.), can cause extensive defoliation (Fig. 2) and yield loss. These diseases account for combined losses and management costs that may exceed U.S. \$50 million in a single year in Georgia alone (14). Management of these diseases is largely dependent upon multiple applications of various fungicides. When resistance to benomyl in both leaf spot pathogens developed in the mid 1970s, chlorothalonil became the standard fungicide for leaf spot control (12). Additional options became available for leaf spot control in 1994 with registration of the ergosterol biosynthesis inhibiting fungicides propiconazole and tebuconazole for use on peanut. Both of these fungicides improved the control of one or both leaf spot diseases compared to chlorothalonil alone (1,7). In addition, tebuconazole provides control of southern stem rot (Sclerotium rolfsii Sacc.) and Rhizoctonia limb rot (Rhizoctonia solani Kühn). In 1997, azoxystrobin was registered for use on peanut for control of leaf spot diseases, southern stem rot, and Rhizoctonia limb rot. All of these fungicides are recommended for use in spray regimes utilizing two or more fungicides, with applications every 14 days beginning approximately 30 days after planting (9).
\end{abstract}




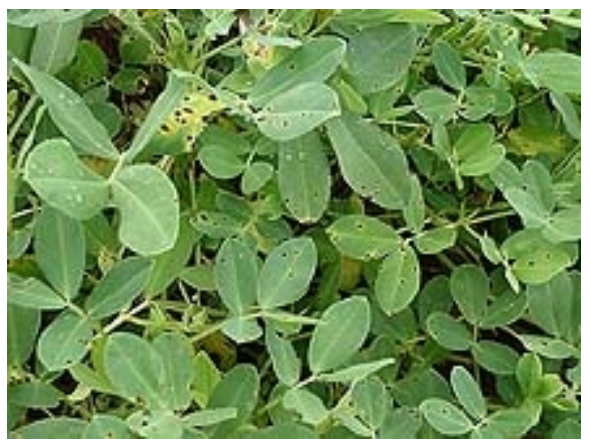

Fig. 1. Early leaf spot of peanut caused by Cercospora arachidicola.

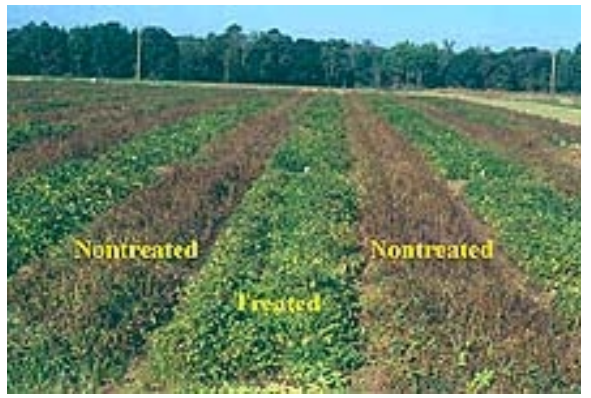

Fig. 2. Alternating beds of peanut plants that received foliar fungicides (Treated) and those that received no fungicides (Nontreated). Plants in the nontreated beds were completely defoliated by early leaf spot.

Pyraclostrobin is a new strobilurin-type fungicide that has shown activity against C. arachidicola and C. personatum and has just received registration for use on peanut in the U.S. The purpose of this work was to determine the effects of three rates of pyraclostrobin applied full-season in standard 14-day spray schedules as well as in 21- and 28-day schedules on leaf spot diseases of peanut.

Of particular interest was comparison of a range of rates of this new fungicide to chlorothalonil, tebuconazole, and azoxystrobin applied in comparable spray programs.

\section{Pyraclostrobin Rate and Spray I nterval Studies}

Peanut seed of cv. Georgia Green (18 seed/ $\mathrm{m}$ of row) were planted in a field of Tifton loamy sand at the Coastal Plain Experiment Station, Lang Farm, Tifton, Georgia, on 29 May 1998, 24 May 1999, and 17 May 2000, and in a field of Faceville sandy loam at the Southwest Georgia Branch Station, Plains, Georgia, on 4 May 1999 and 10 May 2000. All fields had been planted to cotton (Gossypium hirsutum L.) the previous year but had been planted to peanut two years prior. Plots received aldicarb (Temik 15G, Bayer CropScience, Research Triangle Park, NC) (0.75 to $1.0 \mathrm{~kg}$ a.i./ ha) in-furrow at planting. At Tifton, row spacing was a uniform $0.91 \mathrm{~m}(1.83 \mathrm{~m}$ bed). At Plains, rows were $0.71 \mathrm{~m}$ apart within the bed and $0.91 \mathrm{~m}$ between rows in adjacent beds $(1.63 \mathrm{~m}$ bed). All plots were $7.6 \mathrm{~m}$ long by $1.8 \mathrm{~m}$ wide and were separated by two nonsprayed border rows (Fig. 2). Blocks were separated by $2.4 \mathrm{~m}$ fallow alleys. At Tifton, peanut debris from nontreated plots from the previous year was spread in the border rows as an additional inoculum source. Treatments were arranged in a randomized complete block design with four replications.

In 1998, treatments consisted of a (i) nontreated control; (ii) 112, (iii) 168, and (iv) $224 \mathrm{~g}$ a.i./ ha of pyraclostrobin (Headline 2.09 EC, BASF Corp, Research Triangle Park, NC) in the first six sprays of a seven spray regime, with chlorothalonil (Bravo Ultrex 82.5 WDG, Syngenta Crop Protection, Greensboro, NC) applied at $1.26 \mathrm{~kg}$ a.i./ ha in the seventh spray; (v) $1.26 \mathrm{~kg}$ a.i./ ha of chlorothalonil in all seven sprays; (vi) $227 \mathrm{~g}$ a.i./ ha of tebuconazole (Folicur 3.6 F, Bayer CropScience, Research Triangle Park, NC) applied in all seven sprays; and (vii) $1.26 \mathrm{~kg}$ a.i./ ha of chlorothalonil applied in sprays one, two, and seven, and $227 \mathrm{~g}$ a.i./ ha of tebuconazole applied in sprays three to six. In 1998, all 
treatments were applied at 14-day intervals, with initial application 41 days after planting.

In 1999 and 2000, treatments at Tifton included seven similar treatments plus applications of all three rates of pyraclostrobin, chlorothalonil, and tebuconazole at the respective rates at 21- and 28-day intervals for all five and four applications, respectively. In 1999 and 2000, all pyraclostrobin treatments were applied for all applications with no chlorothalonil application. Treatments at Plains in 1999 and 2000 were similar to those at Tifton, except that treatments also included 14- and 28-day interval applications of the strobilurin fungicide azoxystrobin (337 g a.i./ ha) (Abound 2.08F, Syngenta Crop Protection, Greensboro, NC) and only 14- and 28-day spray intervals were used. All subsequent listings of fungicide rates will refer to amount of a.i./ ha.

Initial applications were made 35 to 38 days after planting in all tests in 1999 and 2000 and all spray regimes began on the same day in each respective year and location. In all tests, 14-day regimes received a total of seven applications. Plots sprayed on 21- and 28-day spray schedules resulted in a total of five and four applications, respectively.

Fungicide applications were made using a multiple-boom tractor-mounted $\mathrm{CO}_{2}$-propellant sprayer. Each boom was equipped with three D3-23 hollow-cone spray nozzles per row. Fungicides were applied in 114 liter of water/ ha at a pressure of $345 \mathrm{kPa}$. The tractor traveled all plots each time an application was made to ensure that differences in soil compaction or limb damage (2) due to tractor traffic would not confound treatment effects on yield.

Leaf spot was assessed for each plot by use of the Florida 1 to 10 scale, where $1=$ no leaf spot and $10=$ plants completely defoliated and dead because of leaf spot (5). Values of 1 through 4 on the scale reflect increasing incidence of leaflets with spots and occurrence of spots in lower versus upper canopy of the plots. Values 4 through 10 reflect increasing levels of defoliation (5). For the purposes of this paper, this rating of the combination of disease severity on existing leaves and level of defoliation will be referred to as leaf spot intensity. Leaf spot intensity was rated several times during the season in each test. Final ratings were made immediately prior to digging and inverting the peanut plants. Subsequent indications of leaf spot intensity in this paper refer to the final intensity rating. Plants were dug and inverted on 14 Oct 1998, 4 Oct 1999, and 5 Oct 2000 at Tifton and on 23 Sep 1999 and 21 Sep 2000 at Plains. Loci of southern stem rot were counted for each plot of all treatments except the nontreated plots in all tests except at Plains in 2000, immediately after plants were inverted. A locus represented $31 \mathrm{~cm}$ or less of linear row with one or more plants infected (11). Incidence of stem rot was calculated as the percentage of 31 $\mathrm{cm}$ row sections with symptoms of stem rot and/ or signs of the pathogen. At Plains in 2000, a severe infestation of Cylindrocladium black rot (Cylindrocladium parasiticum Crous, Wingfield, \&Alfenas) prevented rating of the plots for southern stem rot. In that test, the percentage of the row length showing symptoms of wilting or death of plants caused by C. parasiticum was determined for each plot immediately prior to the plots being inverted.

Plants were allowed to dry in the wind-row for 3 to 7 days and pods were harvested mechanically. Pods were dried to $12 \% \mathrm{w} / \mathrm{w}$ moisture and yields (kg/ ha) were determined for each plot for treatment comparisons.

Leaf spot intensity ratings, the incidence of southern stem rot, and pod yield were used for treatment comparisons. Data were subjected to analyses of variance (13). Results from 1998 were analyzed separately, but in 1999 and 2000 , tests were analyzed across years within each location. Fisher's protected least significant differences were calculated for mean separations (13). All subsequent reference to significant effects of factors, interactions, or differences among means indicates significance at $\mathrm{P}<0.05$, unless otherwise stated. Linear regression analyses were used to examine the effects of increasing rates of pyraclostrobin within the range of 112 to $224 \mathrm{~g} /$ ha on leaf spot intensity and pod yield for each spray schedule. Nontreated plots were not included in the regression analyses. Regression equations describing significant linear responses in these tests should not be used to extrapolate expected leaf spot intensity for rates of pyraclostrobin less than $112 \mathrm{~g} / \mathrm{ha}$.

Results. Leaf spot epidemic severity across the various tests ranged from moderate to extremely heavy. Early leaf spot was the predominant foliar disease in all tests. 
1998. In 1998, all fungicide treatments resulted in lower leaf spot intensity ratings $(\mathrm{P}<0.05)$ and higher yields $(\mathrm{P}<0.05)$ than the nontreated plots $($ Fig. 3$)$. Regression analysis indicated there was no significant $(\mathrm{P}>0.09)$ improvement in leaf spot control with additional pyraclostrobin above $112 \mathrm{~g} / \mathrm{ha}$. Leaf spot intensity ratings were lower $(\mathrm{P}<0.05)$ in all pyraclostrobin treatments than in treatments that received chlorothalonil alone or block applications of chlorothalonil and tebuconazole (Fig. 3). Incidence of southern stem rot was 6.5, 5.0 , and $5.0 \%$ for 112,168 , and $224 \mathrm{~g} /$ ha of pyraclostrobin, respectively, which was similar $(\mathrm{P}>0.05)$ to incidence of $7 \%$ in plots treated with tebuconazole and significantly lower than the 17 and $13 \%(\mathrm{LSD}=6.1)$ in plots treated with chlorothalonil or the chlorothalonil-tebuconazole block. There was no significant yield response $(\mathrm{P}>0.05)$ to addition of pyraclostrobin above rates of $112 \mathrm{~g} / \mathrm{ha}$. Plots that received 112 or $224 \mathrm{~g} /$ ha of pyraclostrobin had yields that were higher $(\mathrm{P}<0.05)$ than those treated with chlorothalonil alone (Fig. 3$)$.

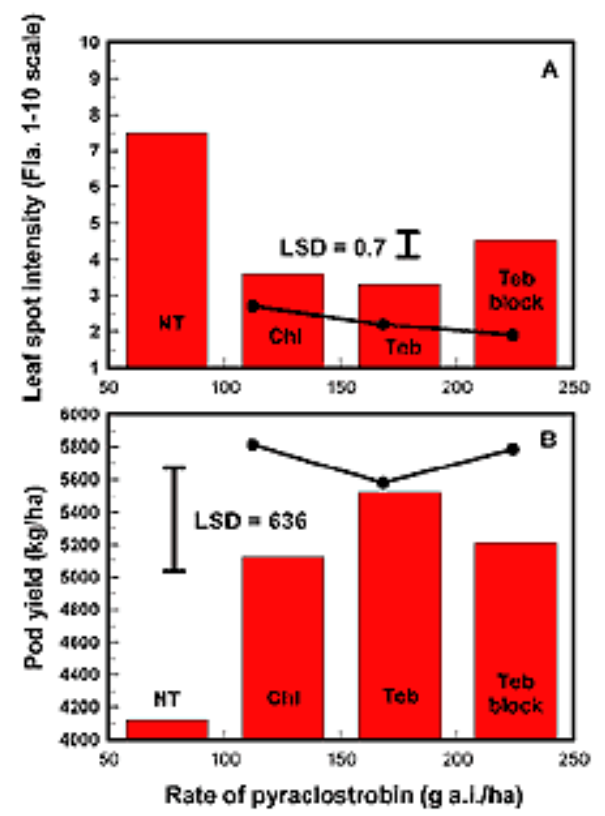

Fig. 3. Effect of increasing rates of pyraclostrobin applied at 14-day intervals on final intensity of early leaf spot (A) and pod yield (B) of peanut at Tifton, Georgia, in 1998. Rate response to pyraclostrobin is indicated with the solid black line, compared to nontreated (NT) plots, fullseason ( 7 sprays) applications of 1.26 $\mathrm{kg} / \mathrm{ha}$ of chlorothalonil (Chl) or $227 \mathrm{~g} / \mathrm{ha}$ of tebuconazole (Teb), and block applications of $1.26 \mathrm{~kg} / \mathrm{ha}$ of chlorothalonil (sprays 1 , 2 , and 7) and $227 \mathrm{~g} /$ ha of tebuconazole (sprays 3 to 6) (Teb block), represented by vertical red bars. The vertical bars do not correspond with any rate on the x-axis.

1999-2000. Foliar Disease Control. Although year effects on leaf spot intensity were significant $(\mathrm{P}<0.05)$ at Plains, the relative treatment effects were consistent across both years in both locations. There was no significant $(\mathrm{P}>$ 0.05 ) year $\times$ treatment interaction at either location; therefore, data were pooled for those years. At Plains, there was no significant $(P>0.05)$ improvement in leaf spot control with rates above $112 \mathrm{~g} /$ ha for the 14- or 28-day schedules (Fig. 4). Leaf spot ratings from plots treated with pyraclostrobin at $168 \mathrm{~g} / \mathrm{ha}$ or higher on a 14-day schedule were lower $(\mathrm{P}<0.05)$ than those from plots treated with chlorothalonil, tebuconazole, or azoxystrobin on the same schedule. 


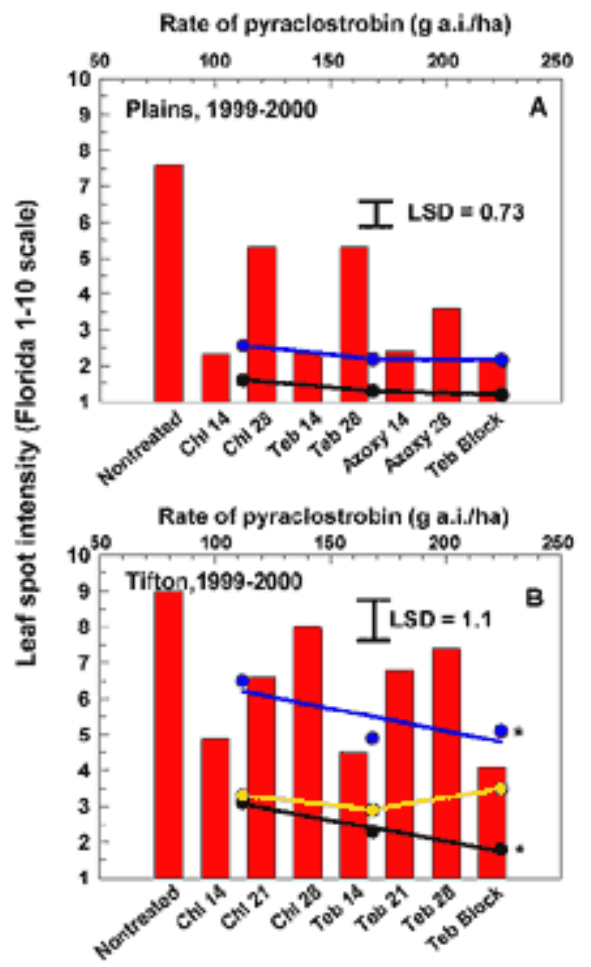

Fig. 4. Effect of rate and application interval of pyraclostrobin (pyr) on final intensity of early leaf spot (ELS) of peanut at (A) Plains, Georgia, and (B) Tifton, Georgia, in 1999 and 2000. The 14-, 21-, and 28-day application intervals for pyraclostrobin are depicted by black, yellow, and blue lines, respectively. At Plains, there was no significant $(P>0.05)$ rate response of early leaf spot to pyraclostrobin applied on a 14- or 28-day schedule. An asterisk (*) in the graph indicates there was a significant $(P<0.05)$ linear response to rate of pyraclostrobin. At Tifton, ELS $=4.3-0.01 * \operatorname{pyr}\left(R^{2}=0.29\right)$ for the 14-day schedule; and ELS = 7.7 $0.013 *$ pyr $\left(R^{2}=0.18\right)$ for the 28-day schedule. There was no significant rate response for pyraclostrobin applied on the 21-day schedule. Vertical red bars represent final leaf spot intensity ratings of nontreated plots; plots treated with 1.26 $\mathrm{kg} / \mathrm{ha}$ of chlorothalonil (Chl), $227 \mathrm{~g} / \mathrm{ha}$ of tebuconazole (Teb), or $337 \mathrm{~g} / \mathrm{ha}$ of azoxystrobin (Azoxy) on 14-, 21-, and 28day schedules; and block applications of $1.26 \mathrm{~kg} / \mathrm{ha}$ of chlorothalonil (sprays 1,2 , and 7) and $227 \mathrm{~g} / \mathrm{ha}$ of tebuconazole (sprays 3 to 6 ) on a 14-day schedule (Teb block). Vertical red bars do not correspond to rate values on the $x$-axis. Numbers following the fungicide abbreviations indicate the spray interval in days. There was no year $x$ treatment interaction for either location. Therefore, values listed are the means of two years. 
Early leaf spot control in plots treated with any of the three rates of pyraclostrobin on a 28-day spray schedule was similar $(P>0.05)$ to that in plots treated with chlorothalonil, tebuconazole, or azoxystrobin on a 14-day schedule (Fig. 4).

At Tifton, there was a significant $(\mathrm{P}<0.05)$ linear reduction in leaf spot intensity with increasing rates of pyraclostrobin applied on a 14- or 28-day schedule (Fig. 4). There was no significant $(P>0.05)$ improvement in leaf spot control with rates above $112 \mathrm{~g} /$ ha in the 21-day application regime (Fig. 4). All rates of pyraclostrobin applied on a 14- or 21-day schedule had leaf spot ratings that were lower $(\mathrm{P}<0.05)$ than ratings for standard rates of chlorothalonil or tebuconazole applied on a 14, 21, or 28-day schedule. Application of pyraclostrobin at a rate of $168 \mathrm{~g} /$ ha or higher on a 28-day schedule provided leaf spot control similar $(\mathrm{P}>0.05)$ to control in plots treated with chlorothalonil or tebuconazole on a 14-day schedule.

Soilborne Disease Control. Incidence of southern stem rot was highly variable in Plains in 1999 and in Tifton for both years. In 1999, means of southern stem rot incidence at Plains ranged from $4 \%$ in plots treated with seven applications of tebuconazole on a 14-day schedule to $19.0 \%$ in the highest rate of pyraclostrobin applied on a 14-day schedule. Analysis of variance indicated no significant $(\mathrm{P}>0.05)$ treatment effects. Therefore, no LSD was calculated and that data is not presented. In 2000, incidence of Cylindrocladium black rot ranged from 44.5 to $69.5 \%$, but was highly variable across the field. Analysis of variance indicated no significant $(\mathrm{P}>0.05)$ treatment effects on this disease; therefore these data are not presented.

Analysis of variance indicated significant $(P<0.05)$ treatment effects on incidence of southern stem rot across both years at Tifton. However, incidence ranged from 14.3 to $23.5 \%$, and no treatment had incidence that differed ( $\mathrm{P}>$ 0.05) from 16.3\% (LSD = 7.6) of full-season applications of chlorothalonil alone (data not presented).

Pod Yield. Yields at Plains in 1999 were high but very variable. Only treatments of pyraclostrobin applied at $112 \mathrm{~g} /$ ha on a 14-day schedule and 224 $\mathrm{g} /$ ha on a 28-day schedule had yields that were higher $(\mathrm{P}<0.05)$ than that of the nontreated control (Fig. 5). There was no significant $(P>0.05)$ yield response to rates of pyraclostrobin above $112 \mathrm{~g} / \mathrm{ha}$ applied on a 14- or 28-day schedule. (Fig. 5). Largely because of the Cylindrocladium black rot infestations, yields were very low in all treatments at Plains in 2000. Yields ranged from 1627 to $2771 \mathrm{~kg} / \mathrm{ha}$, but there were no significant $(\mathrm{P}>0.05)$ treatment effects on yield (data not shown). 

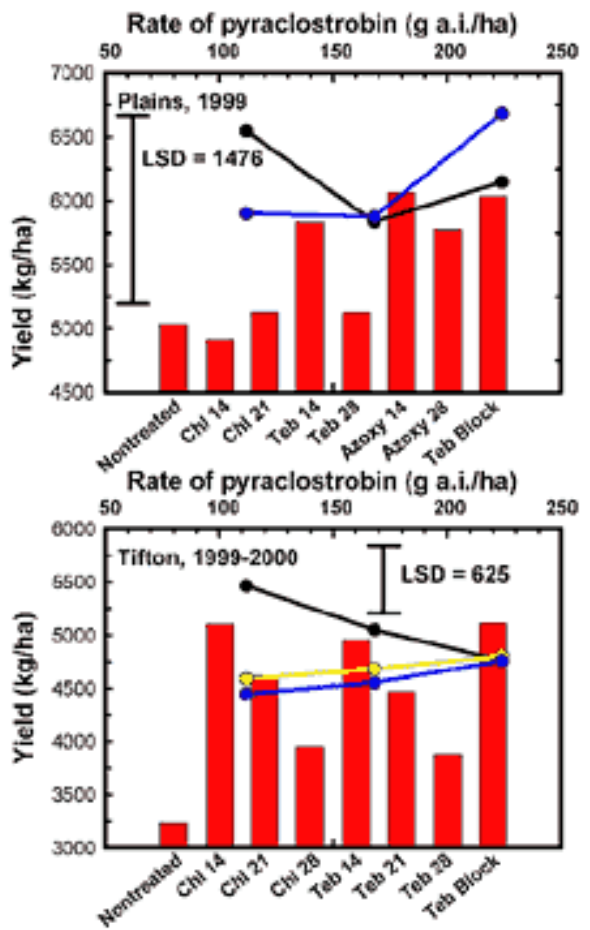

Fig. 5. Effect of rate and application interval of pyraclostrobin on pod yield of peanut at Plains, Georgia, in 1999 and Tifton, Georgia, in 1999 and 2000. The 14, 21-, and 28-day application intervals for pyraclostrobin are depicted by black, yellow, and blue lines, respectively. There was no significant increase in yield with increasing rates of pyraclostrobin above $112 \mathrm{~g} / \mathrm{ha}$ for any schedule in either location. Vertical red bars represent yields of Nontreated plots; plots treated with chlorothalonil (Chl), tebuconazole (Teb), and azoxystrobin (Azoxy) on 14-, 21-, or 28-day schedules; and block applications of chlorothalonil (sprays 1, 2, and 7) and tebuconazole (sprays 3 to 6 ) on a 14-day schedule (Teb block). Vertical red bars do not correspond to rate values on the $x$ axis. Numbers following the fungicide abbreviations indicate the spray interval in days. There was no year $\times$ treatment interaction for Tifton. Therefore, values listed for that location are the means from two years.

Across both years at Tifton there was no significant $(\mathrm{P}>0.05)$ increase in yield with application of pyraclostrobin at rates above $112 \mathrm{~g} /$ ha applied on any of the three schedules (Fig. 5). Yields from plots treated with any of the three rates of pyraclostrobin on 14-, 21-, or 28-day schedules were similar to yields from 14day applications of chlorothalonil, tebuconazole, or the chlorothaloniltebuconazole block program.

\section{Potential Utility of Pyraclostrobin in Peanut}

Pyraclostrobin shows great potential for improving early leaf spot control in peanut and may provide a means of reducing the number of fungicide applications. Based on these results, application of pyraclostrobin at rates of 112 $\mathrm{g} /$ ha or higher can provide control of early leaf spot that is superior to that achieved with standard rates of chlorothalonil, tebuconazole, or azoxystrobin applied on a similar schedule. In addition, pyraclostrobin applied on a 21-day schedule was as effective at Tifton as chlorothalonil or tebuconazole applied on a 14-day schedule. At rates of $168 \mathrm{~g} / \mathrm{ha}$ or higher, application on a 28-day schedule provided control similar to that of chlorothalonil or tebuconazole on a 14-day schedule at both locations. 
Application of chlorothalonil (6), or alternating applications of chlorothalonil and tebuconazole or azoxystrobin at 21-day or longer intervals, can provide good control of early and late leaf spot when combined with a cultivar possessing moderate levels of resistance to those pathogens. This would be especially relevant when used with cultural practices such as conservation tillage, which also help suppress leaf spot epidemics (10). However, pyraclostrobin is the first fungicide registered for use on peanut that can provide adequate control when applied on a 21-day schedule on a susceptible cultivar under conditions conducive for development of severe epidemics of early leaf spot. The use of pyraclostrobin in fields where moderately resistant cultivars are grown or where conservation tillage practices are used might further reduce the numbers of fungicide applications needed for leaf spot management. Although all treatments in these experiments were applied on a regular schedule, pyraclostrobin might be of even greater utility if applied according to a weatherbased advisory such as AU-Pnuts (8).

For the past three years, early leaf spot has been the predominant foliar disease in peanut in most of Georgia. Although most currently recommended fungicides have similar relative activity against early and late leaf spots, very little late leaf spot occurred in any of these tests. Therefore, the efficacy of pyraclostrobin for control of late leaf spot also needs to be determined.

Control of early leaf spot with fewer applications of a more effective fungicide may also allow direct savings in fungicide costs. However, the cost of pyraclostrobin for use on peanut is not known at this time. Even if direct fungicide costs of fewer sprays of pyraclostrobin are similar to higher numbers of applications of other fungicides, use of pyraclostrobin at extended spray intervals may represent potential savings in time, labor, fuel, and equipment costs required for early leaf spot control. Reduced tractor traffic in the field may also help prevent predisposition to other diseases by tire damage to limbs of the peanut plants (2). The potential benefits from reduced tractor traffic were not addressed in this study since all plots had the same traffic, regardless of the number of fungicide applications they received.

Optimal integration of pyraclostrobin into peanut disease control systems will require consideration of several factors in addition to its efficacy for control of early leaf spot. The potential for development of resistance to pyraclostrobin and other quinone outside inhibitor fungicides must be addressed. Azoxystrobin is already being used for disease control in peanut. Problems with resistance of Mycosphaerella fijiensis to the strobilurin fungicide trifloxystrobin have been reported since that fungicide has been used for control of black sigatoka on banana (4). General guidelines developed by the Fungicide Resistance Action Committee for use of strobilurin fungicides on crops receiving three or more fungicide sprays suggest that strobilurin fungicides be restricted to no more than 30 to $50 \%$ of the applications made in a given season and to no more than three sequential sprays (3). Full season applications of strobilurin fungicides such as those used in these tests would not be compliant with those guidelines or with product registration labels. However, full-season application of these fungicides provides a comparison for early leaf spot control that is not confounded with different mixing partners or times of application of one fungicide versus another, relative to early leaf spot epidemic development. In addition, use of full-season applications of pyraclostrobin provides an efficacy baseline for these locations for monitoring the relative performance of this fungicide and chlorothalonil over time. Determining the optimum timing of pyraclostrobin in application regimes with fungicides with different modes of action may be critical for sustained successful use of pyraclostrobin for control of early leaf spot in peanut.

In most fields where peanut is grown in the southeastern U.S., fungicides are needed for control of southern stem rot and/ or Rhizoctonia limb rot (Rhizoctonia solani) as well as foliar diseases. Currently, tebuconazole, flutolanil and azoxystrobin are registered and recommended for control of these important soilborne diseases. Results from these tests were inconclusive regarding the efficacy of this fungicide on southern stem rot. Rhizoctonia limb rot occurred at levels too low to evaluate, so these tests yielded no information on control of that disease. Other tests addressing rate and application requirements for control of these two diseases with pyraclostrobin are in progress. Characterization of the effects of pyraclostrobin on these diseases and determination of optimal rate and application timings will be critical for 
incorporation into the overall disease management program in peanut. Based on the lack of improvement in early leaf spot control achieved with the addition of higher rates of pyraclostrobin in this study, recommended rates for use of pyraclostrobin in peanut may be determined by rates required to provide needed control of southern stem rot and Rhizoctonia limb rot.

If pyraclostrobin does not provide adequate control of southern stem rot and Rhizoctonia limb rot, it may be necessary to incorporate the use of tebuconazole or flutolanil into fungicide regimes for management of multiple fungal diseases.

\section{Summary}

Pyraclostrobin is a new strobilurin-type fungicide that shows great potential for improving control of early leaf spot of peanut. These tests indicate the level of control of early leaf spot provided by pyraclostrobin applied five times at 21day intervals is as good as that provided by currently available fungicides chlorothalonil and tebuconazole applied seven times at standard rates at 14-day intervals. Recommendations for use of pyraclostrobin on peanut must take into consideration the potential development of resistance and the necessity of integrated management of both foliar diseases and fungal diseases of the stem and limbs.

\section{Literature Cited}

1. Brenneman, T. B., and Murphy, A. P. 1991. Activity of tebuconazole on Cercosporidium personatum, a foliar pathogen of peanut. Plant Dis. 75:699-703.

2. Brenneman, T. B., and Sumner, D. R. 1989. Effects of chemigated and conventionally sprayed tebuconazole and tractor traffic on peanut diseases and pod yields. Plant Dis. 73:843846.

3. Brent, K. J., and Holloman, D. W. 1998. Fungicide resistance: The assessment of risk. Fungicide Resistance Action Committee Monograph No. 2. Global Crop Protection Federation, Brussels.

4. Chin, K. M., Wirz, M., and Laird, D. 2001. Sensitivity of Mycosphaerella fijiensis from banana to trifloxystrobin. Plant Dis. 85:1264-1270.

5. Chiteka, Z. A., Gorbet, D. W., Shokes, F. M., Kucharek, T. A., and Knauft, D. A. 1988. Components of resistance to late leaf spot in peanut. I. Levels of variabilityimplications for selection. Peanut Sci. 15:25-30.

6. Culbreath, A. K., Brenneman, T. B., and Kvien, K. C. 1992. Use of a resistant peanut cultivar with copper fungicides and reduced fungicide applications for control of late leaf spot. Crop Protection 11:361-365.

7. Culbreath, A. K., Brenneman, T. B., Reynolds, K., Hammond, J . M., and Reynolds, K. L. 1995. Tank mix combinations of propiconazole and chlorothalonil for control of leaf spot diseases of peanut. Peanut Sci. 22:101-105.

8. Jacobi, J. C., Backman, P. A., Davis, D. P., and Brannen, P. M. 1995. AU-Pnuts Advisory I: Development of a rule-based system for scheduling peanut leaf spot fungicide applications. Plant Dis. 79:666-671.

9. Kemerait, R., Brenneman, T. B., and Culbreath, A. K. 2001. Peanut disease control. In: Georgia Pest Handbook. P. Guillebeau, ed. The University of Georgia Special Bulletin 28.

10. Monfort, W. S., Culbreath, A. K., and Brenneman, T. B. 2001. Response of three cultivars to tillage practices and application timing of fungicide regimes for early leaf spot. (Abstr.) Phytopathology 91:S202.

11. Rodriguez-Kabana, R., Backman, P. A., and Williams, J . C. 1975. Determination of yield losses to Sclerotium rolfsii in peanut fields. Plant Dis. Rep. 59:855-858.

12. Smith, D. H., and Littrell, R. H. 1980. Management of peanut foliar diseases with fungicides. Plant Dis. 64:356-360.

13. Steel, R. G. B., and Torrie, J. H. 1980. Principles and Procedures of Statistics. McGraw-Hill, New York.

14. Williams-Woodward, J . L. 1999. Georgia Plant Disease Loss Estimates. University of Georgia Extension Publication Path 99-002. 